This page intentionally left blank 


\section{LAW AND THE}

\section{Contradictions}

\section{of THE Disability}

Rights Movement

Samuel R. Bagenstos

Yale University Press

New Haven E London 
Published with assistance from the foundation established in memory of Philip Hamilton McMillan of the Class of 1894, Yale College.

Copyright ( 2009 by Samuel R. Bagenstos. All rights reserved.

This book may not be reproduced, in whole or in part, including

illustrations, in any form (beyond that copying permitted by

Sections 107 and 108 of the U.S. Copyright Law and except by

reviewers for the public press), without written permission from the publishers.

Set in Electra type by Tseng Information Systems, Inc.

Printed in the United States of America.

Library of Congress Cataloging-in-Publication Data

Bagenstos, Samuel R.

Law and the contradictions of the disability rights movement / Samuel R. Bagenstos. p. $\mathrm{cm}$.

Includes bibliographical references and index.

ISBN 978-0-300-12449-1 (cloth : alk. paper) 1. People with disabilitiesLegal status, laws, etc. - United States. 2. Discrimination against people with disabilities - Law and legislation - United States. 3. People with disabilitiesCivil rights - United States. I. Title.

$$
\begin{gathered}
\mathrm{KF} 480 . \mathrm{B} 3452009 \\
342.7308^{\prime} 7-\mathrm{dc} 22 \\
2008046981
\end{gathered}
$$

A catalogue record for this book is available from the British Library.

This paper meets the requirements of ANSI/NISO Z39.48-1992 (Permanence of Paper).

It contains 30 percent postconsumer waste $(\mathrm{PCW})$ and is certified by the Forest Stewardship Council (FSC).

$\begin{array}{llllllllll}10 & 9 & 8 & 7 & 6 & 5 & 4 & 3 & 2 & 1\end{array}$ 
For Harry and Leila 
This page intentionally left blank 